Bull. Egypt. Soc. Physiol. Sci. Vol. (42) Issue (1), 63-73

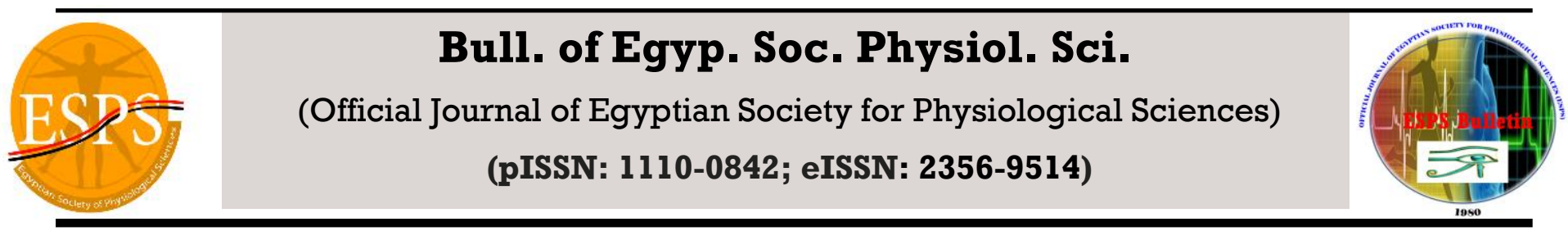

\title{
Beneficial antipruritic effects of lowering Interleukin -17 and/or IgE by anti-IgE monoclonal antibodies and PPAR gamma agonist in experimentally induced atopic dermatitis in mice
}

\author{
Magdy Abdulaziz Ragab ${ }^{1}$, Wafaa Ibrahim Abdallah ${ }^{1}$, Rania Al-Saied Abdel Maksoud ${ }^{1}$, Dina \\ Ragheb Hassan Nasser ${ }^{2}$, Nesrine M. El Azhary ${ }^{3}$
}

1 Professor of Dermatology, Venerology and Andrology, Department of Dermatology, Venerology and Andrology; Faculty of Medicine, University of Alexandria

2 MBBCh, Ms, MD Dermatology, Venerology and Andrology, Dermatology consultant at the Egyptian Ministry of Health hospitals, Egypt.

3 Associate Professor of Medical Physiology, Department of Medical Physiology; Faculty of Medicine, University of Alexandria, Egypt

Submit Date:22 June 2021

Revise Date:5 Oct 2021

Accept Date : 9 Oct 2021

\section{Keywords \\ Antipruritic \\ PPAR gamma \\ agonist \\ anti $\operatorname{IgE}$}

\section{Abstract}

Itching is a major complaint in chronic allergic dermatitis. High levels of interleukin -17 (IL -17) and immunoglobulin E (Ig E) have been suspected to play a major role in this inflammatory condition. The aim of this work was to study the potential antipruritic effect of lowering IL-17 and /or IgE by anti IgE monoclonal antibodies and peroxisome proliferator-activated receptor gamma (PPAR $\gamma$ ) agonist in an experimental model of atopic dermatitis (AD) induced by oxazolone in mice. Methods: Fifty female mice were randomly assigned to 4 groups. AD-like lesions were induced in group 2, 3 and 4 by application of $5 \%$ oxazolone followed by $0.1 \%$ oxazolone to the mice skin (chronic $\mathrm{AD})$. Group 2 mice were left untreated while those in group 3 and 4 received anti $\operatorname{IgE}$ monoclonal antibodies (omalizumab) and PPAR $\gamma$ agonist (pioglitazone) respectively. Results: Administration of either anti IgE monoclonal antibodies (omalizumab) and PPAR $\gamma$ agonist (pioglitazone) significantly reduced scratching behavior in treated mice. This was accompanied by significant decrease of the elevated levels of IL-17 and IgE by both drugs. IL-17 suppression was better with pioglitazone while IgE suppression was more significant with omalizumab. Dermoscopic, histological examination and transepidermal water loss (TEWL) also showed significant improvement. Conclusions: Both anti IgE monoclonal antibodies (omalizumab) and PPAR $\gamma$ agonist (pioglitazone) offer antipruritic effects in AD by reducing IL-17, Ig E and transepidermal water loss.

Corresponding author: Nesrine Mounir El Azhary, Medical physiology department, Moassah Campus, Faculty of Medicine, Alexandria, Egypt. E-mail: mouniryousef2005@yahoo.fr 


\section{INTRODUCTION}

Itching or pruritus is a somatic sensation carried by type $\mathrm{C}$ fibers to the spinothalamic tract and the somatosensory cortex [1]. It is classified into four types: neurogenic (or systemic) itch that occurs due to diseases in organs other than the skin, psychogenic itch that results from psychologic troubles that drive the patient to scratch normal skin, neuropathic itch resulting from damaged sensory afferents activated without pruritogenic stimuli and pruriceptive itch [2]. The later is the most common type of itch and is due to application of different allergens to the skin.

Itch can be histaminergic due to release of histamine from mast cells upon exposure to endogenous or exogenous substances. It can also be

non-histaminergic, due

to exposure of the skin to certain neuropeptides, cytokines, lipids or proteases as tryptase, derived from mast cells and kallikreins, from keratinocytes upon disruption of the epidermal skin barrier [2,3].

The skin barrier is composed of 4 divisions: microbiome (commensal bacteria that fight skin pathogens), chemical (as antimicrobial peptides that keep skin $\mathrm{pH}$ and lipids), physical (stratum corneum and tight junction proteins) and immunological (resident immune cells as Langerhans cells) [4]. These cells can interplay with other lymphocytes to initiate different immune responses [5].

Atopic dermatitis (AD) is a chronic inflammatory skin disease characterized by intense itching, xerosis and eczematous lesions, in which the skin barrier is disturbed [6,7]. Recently, it has been found that itch represents an interplay between immunology and neuroscience [8]. An immunologic aspect of this disease was discovered: a change in the type of immunoglobulin produced by B-lymphocytes (class switching) from serum immunoglobulin Ig $M$ into Ig E. Skin samples show increased numbers of IgE - bearing Langerhans cells which act as antigen presenting cells to T-helper 2 cells [9] i.e., IgE is mostly the bridge linking antigen recognition by immune cells and mast cells and basophils, present in the skin exposed to antigens [10]. Recently, high $\mathrm{IL}-17$ levels have been reported too. They induce a proinflammatory state and upregulate numerous inflammation-related genes in target cells, fibroblasts and keratinocytes, the predominant cells in the epidermis, having itch receptors, and capable of releasing pruritogenic molecules [11, 12, 13].

Scratching of itchy skin is associated with a sense of pleasantness associated with activation of several parts of the brain as the corpus striatum and the midbrain (reward system), the primary somatosensory cortex (perception) and the insular cortex [14]. Unfortunately, repeated scratching leads to additional mechanical injury of the skin and stimulates the keratinocytes to produce more inflammatory cytokines [3]. Several substances have been used to inhibit scratching as histamine receptor -1 antagonists and naltrexone [15].

In the current study, we investigated the potential antipruritic effects of anti $\operatorname{IgE}$ monoclonal antibodies (omalizumab) and PPAR- $\gamma$ agonist (pioglitazone) in experimental chronic ADlike lesions induced by oxazolone in mice.

\section{Material and methods}

All animal care and experimental procedures were carried out in accordance with the National Institutes of Health Animal Care Guidelines (NIH 
publications No. 80-23), and were also approved by the Ethics Committee of Alexandria University. Fifty female mice, 5 weeks old, were purchased from the animal house of the Medical Physiology department and maintained in clean polypropylene cages, at a room temperature of 22-25 degrees centigrade, with free access to standard laboratory show and tap water with a $12 \mathrm{~h} / 12 \mathrm{~h}$ light/dark cycle. After one week adaptation, 50 mice were randomly assigned to four groups:

Group 1(Naïve group): 10 mice in which $100 \%$ ethanol (vehicle) was painted to the right ear and shaved rostral back.

\section{Group 2 (untreated AD):}

Group 2 A : 10 mice exposed to a single application of $20 \mu \mathrm{l}$ of $5 \%$ oxazolone (Sigma USA) dissolved in $100 \%$ ethanol, painted to the right ear and shaved rostral back, to develop acute dermatitis [16].

Group 2B: After initial sensitization as group 2A, another 10 mice were weekly rechallenged with $0.1 \%$ oxazolone solution $(20 \mu 1$ applied to the right ear and $40 \mu \mathrm{l}$ applied to the shaved rostral back), to develop chronic dermatitis [16].

Group 3 (Anti-IgE monoclonal antibodiestreated): After development of chronic dermatitis as in group $2 \mathrm{~B}, 10$ mice received anti- $\operatorname{IgE}$ monoclonal antibodies (omalizumab) subcutaneously, every 5 days in a dose of $4 \mathrm{ml} / \mathrm{Kg}$, starting from the beginning of the $3{ }^{\text {rd }}$ week till the end of the $7^{\text {th }}$ week [17].

\section{Group 4 (PPAR gamma agonist-treated): After} development of chronic dermatitis as in group $2 \mathrm{~B}$, 10 mice received PPAR gamma agonist (pioglitazone) daily by gavage feeding in a dose of $25 \mathrm{mg} / \mathrm{Kg}$ from the beginning of the $3^{\text {rd }}$ week till the end of the $7^{\text {th }}$ week [18].
The following parameters were measured:

a) Scratching behavior was weekly quantified by counting the number of scratches with foreand hind paws for 40 minutes, close to the site of application of oxazolone solutions. Scratching behind the ears, but not on the face, was also counted. When a mouse scratched continuously for about 1 second without stopping, and repeated it more than once, this episode of scratching was counted as one. The results were expressed as the number of scratches in $40 \mathrm{~min}$ [19].

b) Transepidermal water loss was weekly estimated by EnviroDerm Services Tewameter (Dermal measurement system EDS12, UK), to assess the impact of $\mathrm{AD}$ on epidermal barrier function as an objective parameters of disease severity [20].

c) Total serum IgE: Blood samples were collected at beginning, third week and at the end of seventh week. The serum level of total IgE was measured by ELISA kit (EIAab company) according to the manufacturer's instructions.

d) Serum IL-17 level: Blood samples were collected at the beginning, third week and at the end of the seventh week. The levels of IL17 were measured by an ELISA kit (EIAab company) according to the manufacturer's instructions.

e) Matsuoka scoring system [21] : The severity of the macroscopic clinical signs of dermatitis was measured by the extent of (1) erythema hemorrhage, (2) scarring/dryness, (3) edema, (4) excoriation /erosion. The following score was given:0 (none), 1 (mild), 2 (moderate) and 3 (severe). 
f) Dermoscopic evaluation was performed by two independent doctors, who were unaware of the histopathological diagnosis, using DERMALITE dermoscope. The severity of dermoscopic signs was scored as 0 (none), 1 (mild),2 (moderate) and 3 (severe), by the extent of (1) background color (dull red, i.e. intense red color, light red, i.e. fading red color, yellowish) and distribution (2) scale color (white, yellow, white + yellow); and distribution (patchy, peripheral, diffuse, central) (3) vascular morphology (dotted, linear, dotted + linear) and distribution (regular, in clusters, patchy, peripheral, in rings).

g) Histopathology: Mice skin samples were sliced and then stained with $\mathrm{H} \& \mathrm{E}$ and toluidine blue to count the mast cells and eosinophils, respectively. The cell density was expressed as the number of cells per five high-power field (400) for each section.

\section{Statistical analysis}

Data processing and analysis were performed by SPSS, version 18.0 Chicago: SPSS Inc. Qualitative data were coded and codes were checked before analysis. Quantitative variables were presented as mean and standard deviation. For qualitative variables, numbers and \% from total were used. Statistical comparisons between groups were performed using Krushal Wallis and Mann-Whitney $U$ test for quantitative variables and Fisher's Exact, Monte Carlo and Chi-Square tests for qualitative variables. Wilcoxon signed ranks test was used in the comparison between different readings of the same variable in group at different times. Linear relationships between quantitative variables were assessed using
Spearman correlation coefficient. All results were interpreted at $5 \%$ level of significance.

\section{Results}

\subsection{Acute dermatitis (Group 2 A mice)}

After a single application of $5 \%$ oxazolone, mice developed acute dermatitis . Compared to group 1 (naïve mice), there was a statistically significant increase in scratching behavior (34.47 \pm 2.9 versus $8.53 \pm 1.6)$, in TEWL $(10.87 \pm 0.83)$, in IL-17 level $(46.2 \pm 3.3 \mathrm{pg} / \mathrm{ml})$, in the mean level of IgE $(42.7 \pm 3.9 \mathrm{ng} / \mathrm{ml})(\mathrm{P}<0.001)$ (Figures 1 and 2). The mean value of Matsuoka score was $9 \pm 1.6$, with predominance of erythema and edema, while the mean value of dermoscopic scoring 5.9 \pm 1.1 , with predominance of patchy erythema and dotted vessels (figure 3a).

\subsection{Chronic untreated AD model (group 2 B mice)}

At the end of the $7^{\text {th }}$ week, compared to acute dermatitis, there was a statistically significant increase in scratching behavior (60.4 \pm 4.5$)$, TEWL (18.2 \pm 1.21$)$, in serum IgE level $(72.5 \pm 8.1 \mathrm{ng} / \mathrm{ml})$, IL$17(88.8 \pm 2.7 \mathrm{pg} / \mathrm{ml})(\mathrm{P}<0.001)($ Figure 1 and 2$)$. Matsuoka score was $9 \pm 1.6$, with predominance of scaling and excoriation (figure 3). Histopathologic examination revealed prominent epidermal hyperplasia, inflammatory infiltrate in contrast to edema and erosion which were more prevalent in the acute dermatitis (figure 4).

\subsection{Chronic AD treated with omalizumab} (group 3) and pioglitazone (Group 4)

A significant decrease in scratching occurred in chronic $\mathrm{AD}$ treated by omalizumab and pioglitazone compared with group 2B (20.5 \pm 2.9 and $23.73 \pm 3.6$ versus $60.4 \pm 4.5$ respectively, $\mathrm{P}<0.001$ ). There was also a significant decrease in TEWL $(7.73 \pm 1.39$ and $4.73 \pm 1.16$ respectively), a lower 
serum Ig E level $(19.3 \pm 3.3$ and $45.01 \pm 8.8 \mathrm{ng} / \mathrm{ml}$ respectively), a lower IL-17 level (72.4 \pm 3.8 and $30.5 \pm 2.7 \mathrm{pg} / \mathrm{ml}$ respectively) (Figures 1 and 2). The mean value of Matsuoka score was $2.9 \pm 0.8$ and $0.87 \pm 0.8$ respectively and the mean value of dermoscopic score was $1.5 \pm 0.5$ and $0.5 \pm 0.6$ respectively (figure 3). This was associated with histopathologic evidence of improvement (figure 4).

Though treatment with PPAR gamma agonist led to a significantly lower Matsuoka score, dermoscopic score, TEWL, IL-17 and higher hydration, it was unable to lower the elevated $\operatorname{IgE}$ as efficiently as anti $\operatorname{IgE}$ monoclonal antibodies.

Results also showed a positive strong correlation between the level of IL-17 and Matsuoka score, dermoscopic score and TEWL. However, there was a weak positive correlation between scratching at the end of the seventh week and both IgE and IL-17 levels.

\section{Scratching behavior in the studied groups}

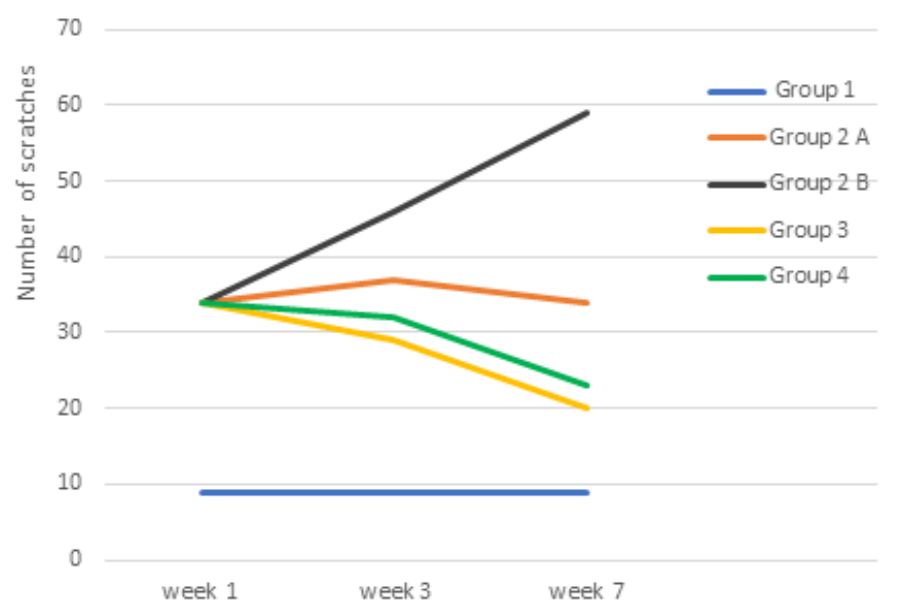

Figure 1: Comparison between the scratching behavior in the studied groups. There was a statistically significant increase in scratching in group $2 \mathrm{~A}$ and $2 \mathrm{~B}$ compared to group 1 (naïve group), in the first and third week. In addition, there was a statistically significant higher scratching in group $2 \mathrm{~B}$ compared to $2 \mathrm{~A}$. In the seventh week, there was a significant decrease in scratching in group 3 and group 4 compared with group $2 \mathrm{~A}$ and $2 \mathrm{~B}(\mathrm{P}<0.001)$.

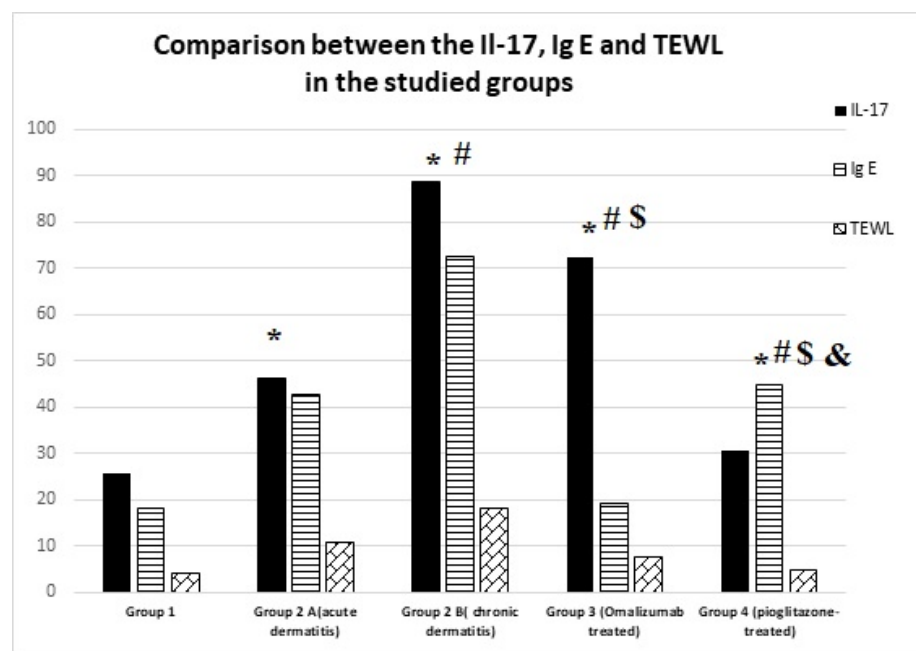

Figure 2: Comparison between the serum IL-17 in pg/ml, Ig E in $\mathrm{ng} / \mathrm{ml}$ and transepidermal water loss (TEWL) in the studied groups .* statistically significant difference compared to group 1. \# Statistically significant difference compared to group 2A. ${ }^{\$}$ statistically significant difference compared to group 2 B. ${ }^{\&}$ statistically significant difference compared to group 3 . 


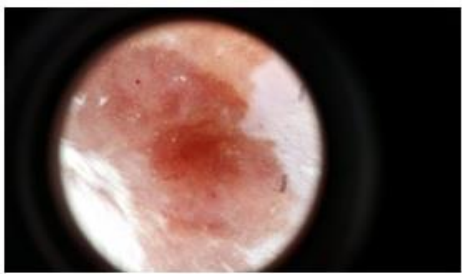

Fig(3a): Acute dermatitis (Group 2A)

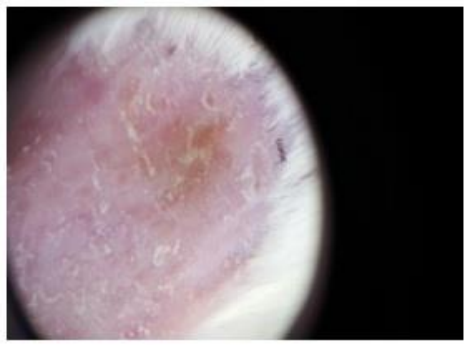

Figure (3c): Chronic $\mathrm{AD}$ treated by omalizumab (Group3)

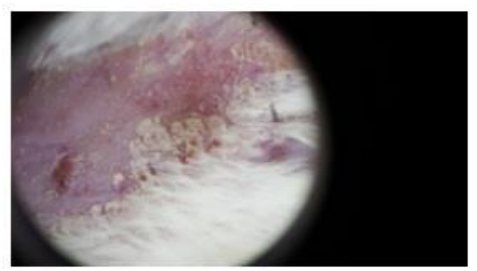

Figure (3b): Chronic AD (Group 2 B)

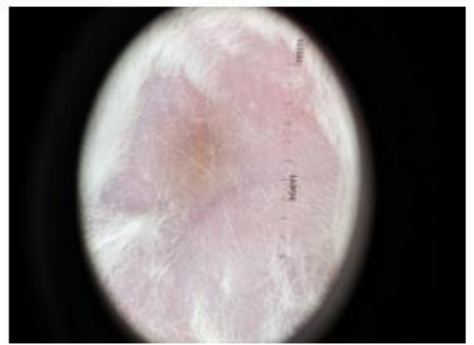

Figure (3d): Chronic $\mathrm{AD}$ treated by pioglitazone (Group 4)

Figure (3): Dermoscopic examination of the skin of the different studied groups . Group 2 A shows predominance of patchy erythema and dotted vessels, while in group $2 \mathrm{~B}$, scaling and excoriation were predominant. Group 3 and 4 , treated with anti Ig E antibodies and PPAR- $\gamma$ agonist shows significantly less redness and scaling.

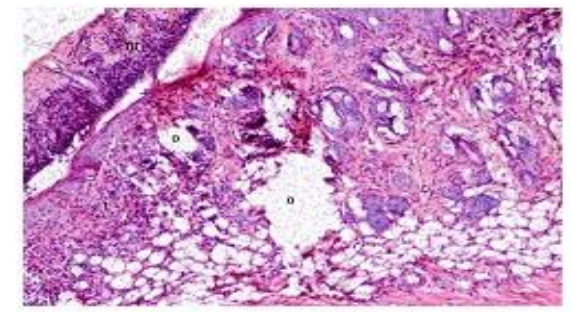

Fig (4a): Acute derma tit is (Group 2A) microg raph showing epidermal thickening (TH), dermal infiltration (I) with focal area of edema $(\mathrm{O})$. (by $\mathrm{H}$ and $\mathrm{E}$ staining)

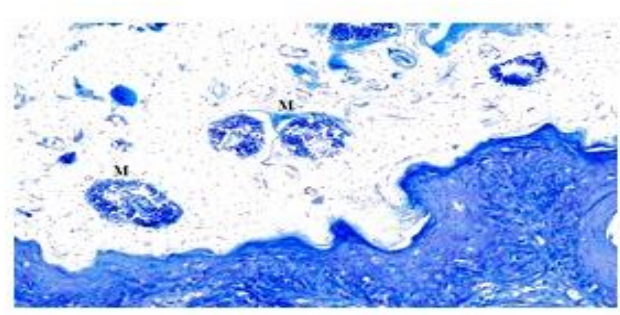

Fig (4c): Acute AD (Group 2A) Toluidine blue staining to illustrate mast (M) cell infiltration

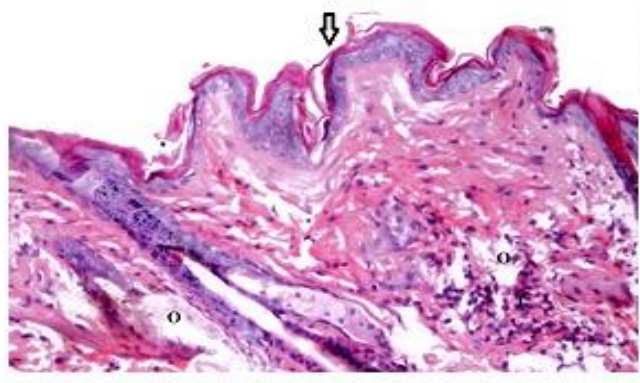

Figure(4e): Chronic AD treated by omalizumab (Group3). Areas of hyperkeratosis (arrow) are still present. Cellular infiltrates (I) are also noticed. Area of edema (O) can be detected compared to control group. (by $\mathrm{H}$ and $\mathrm{E}$ staining)

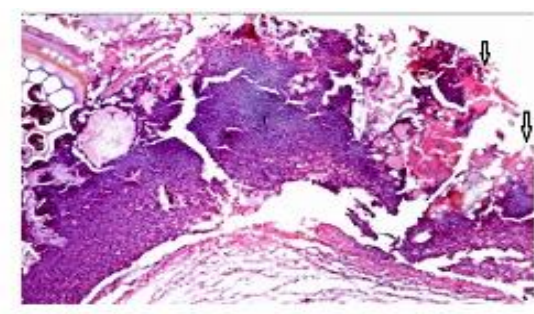

Figure (4b): Chronic AD (Group 2 B)

micrograph showing massive epidermal

thickening with detachment and distortion of its architecture (arrows). Notice massive dermal infiltration( $\mathrm{I}$ ) (by $\mathrm{H}$ and $\mathrm{E}$ staining)

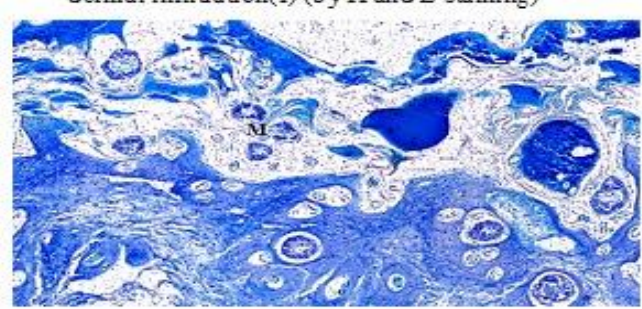

Figure (4d): Chronic AD (Group 2 B) by

toluidine blue showing an abundance of mast cell $(M)$ infiltration in between dermal tissue.

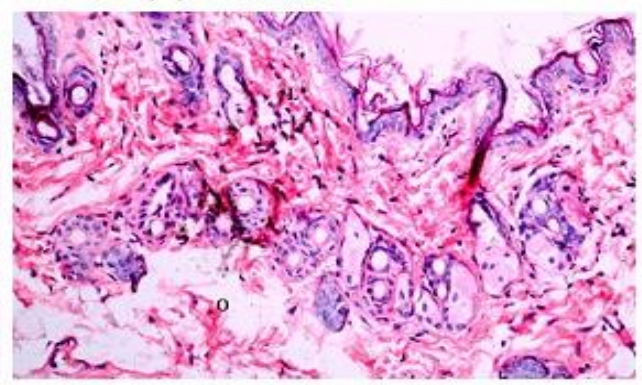

Figure (4f): Chronic AD treated by pioglitazone (Group 4) showing mild cellular infiltration mainly lymphocytes (L) with persistent mild edema $(\mathrm{O})$. Notice restoration of keratin layer. (by $\mathrm{H}$ and $\mathrm{E}$ staining)

Figure (4): Histopathologic examination of skin in the different studied groups. Courtesy of Dr. Noha Mahmoud Zahran, associate professor of Histology and cell biology 


\section{Discussion}

A single application of oxazolone solution induced acute dermatitis. This can be explained by contact sensitivity responses to reactive hapten antigen (oxazolone), which led to cell mediated hypersensitivity reaction. The cutaneous manifestations as redness and itching were associated with a mild increase in TEWL, decrease in hydration, mild epidermal hyperplasia, inflammatory infiltrate and marked edema, compared to the naïve group. These results agree with Man MQ et.al (2008) [16] who described a mild deterioration of TEWL associated with normal hydration upon the initial oxazolone challenge. In the current work, both serum levels of IL-17 and IgE were increased. This was accompanied by increased cellular infiltration, in agreement with Heo W (2015) [22] and his coworkers who reported similar findings in wildtype mice but not in IL-17 knockout mice. Elevated serum level of $\operatorname{IgE}$, may be related to degranulation of mast cells and basophils, and to the elevated serum level of IL-17. In fact, IL-17 may increase IgE levels by multiple mechanisms as increasing $\operatorname{IgE}$ secretion from already existing IgE secreting plasma cells, acceleration of differentiation of $\mathrm{B}$ lymphocytes into $\mathrm{IgE}$ producing plasma cells and changing the class of $\mathrm{B}$ lymphocytes from memory into $\operatorname{IgE}$ secreting plasma cells [23].

Repeated application of oxazolone to the mice skin converted the acute dermatitis into a chronic one, with erosions, scaling and increased itching. Several factors are involved in this conversion. The increased TEWL and decreased hydration that allowed more allergen to traverse the subcutaneous tissue repeatedly. The decreased efficiency of the permeability barrier gives a greater access for the hapten (oxazolone) and increases scratching [24]. In addition, the high serum level of $\operatorname{IgE}$ also enhances the transformation of acute into chronic dermatitis because more $\operatorname{IgE}$ bearing Langerhans cells are available to present the recurrent cutaneous allergen (oxazolone) to T-helper2 cells which promote inflammation [25]. That is why the epidermal hyperplasia, hyperkeratosis, and marked inflammatory infiltrate were more evident in the chronic model than in acute dermatitis [24]. Other researchers also demonstrated diminished levels of three structural protein markers of differentiation (loricrin, involucrin, filaggrin) in the outer nucleated layers of skin upon repeated exposure to oxazolone [16]. Previous studies also emphasized the role of the elevated levels of serum IL-17 which cause a change in expression of genes involved in formation of skin barrier [26,27]. In accordance with the present results, scientists reported that in IL-17 deficient mice, Ig E production was suppressed and skin inflammation was decreased [26-28].

Repeated administration of omalizumab significantly alleviated itching in chronic AD. This antipruritic effect may be due to lowering of Ig E, the main immunoglobulin prevalent in atopic conditions. In fact, omalizumab is an anti $\operatorname{IgE}$ monoclonal antibody that specifically binds to most forms of IgE; weather free in blood, membrane-bound or on the surface of IgEexpressing B lymphocytes [13]. In addition, serum IL-17 was significantly reduced. Previous researchers suggested that Il-17 A+ cells promote IgE production and exert its pro-allergic effect directly at the level of B lymphocytes, which need 
co-stimulation by both $\mathrm{B}$ cell activating factor (BAFF) and IL-17A to ensure their survival and differentiation into plasma cells [29,30]. The beneficial use of omalizumab in other allergic conditions has been recorded as in case of asthma [31].

Peroxisome proliferator-activated receptors (PPARs) are nuclear hormone receptors that regulate gene expression and inflammatory responses. They also modulate various skin functions as keratinocyte proliferation, epidermal barrier formation, wound healing and sebum production. Pioglitazone is a PPAR $\gamma$ agonist that has been successfully used for the treatment of type 2 diabetes mellitus [32].

Pioglitazone in a dose of $25 \mathrm{mg} / \mathrm{Kg}$ was also able to significantly reduce scratching in chronic AD. This antipruritic effect may be explained by improvement of the permeability barrier functions possibly by upregulation of aquaporin 3 in skin keratinocytes, a main player in barrier function and skin hydration [33]. Other factors as stimulating the formation of lipids in the epidermis (lamellar body and lamellar membranes) and increased involucrin levels (an important marker of keratinocyte differentiation) can not be ignored [34,35]. In addition, as a PPAR $\gamma$ agonist, pioglitazone can also selectively hinder or even stop the differentiation of lymphocytes into $\mathrm{T}$ helper-17 cells, the main site of secretion of IL$17[36]$. It is to be noted that pioglitazone showed effectiveness in treating other atopic conditions as lowering symptoms of anaphylaxis and recruitment of inflammatory cells in the lung, as well as serum IgE, in an experimental model of acute bronchial asthma [35, 37].

\section{Conclusions}

Both anti $\operatorname{IgE}$ monoclonal antibody (omalizumab) and PPAR $\gamma$ agonist (pioglitazone) have promising antipruritic potentials in atopic dermatitis. This beneficial effect is mostly due to reduction of the elevated IL-17, IgE and TEWL.

\section{Acknowledgement}

We greatly thank Dr. Noha Mahmoud Zahran, associate professor of Histology and Cell Biology, for her great help with the histopathology of the slides.

\section{Disclosure Statement}

The authors have no conflicts of interest to declare.

Funding This study was self-funded.

\section{References}

1. Jeffry J, Kim S, Chen ZF. Itch Signaling in the Nervous System . Physiology 26: 286-92, 2011.

2. Garibyan L, Rheingold CG, Lerner EA. Understanding the pathophysiology of itch. Dermatol Ther 26 (2): 84-91, 2013.

\section{Umehara Y, Kiatsurayanon C, Trujillo-Paez} JV, Chieosilapatham P, Peng G, Yue H et.

al. Intractable Itch in Atopic Dermatitis: Causes and Treatments. Biomedicines 9(3):229, 2021.

\section{Nguyen H , Trujillo-Paez J. V , Umehara Y,} Yue H , Peng G , Kiatsurayanon C., et.al . Role of Antimicrobial Peptides in Skin Barrier Repair in Individuals with Atopic Dermatitis. Int J Mol Sci 21(20): 7607, 2020.

5. Egawa G, Kabashima K. Multifactorial skin barrier deficiency and atopic dermatitis: essential topics to prevent atopic march. $J$ Allergy Clin Immunol 138: 350-8, 2016. 
6. Kabashima K, Otsuka A, Nommura $\mathbf{T}$. Linking skin pollution to atopic dermatitis. Nat Immunol 18: 5-6, 2016.

7. O'Regan GM, Irvine AD. The role of filaggrin in the atopic diathesis. Clin Exp Allergy 40: 965-72, 2010.

8. Cevikbas F, Lerner EA. Physiology and Pathophysiology of Itch. Physiol Rev 100 (3): 945-82, 2020.

\section{Karagiannidou A, Botskariova S, Farmaki}

E Imvrios G Mavroudi A . Atopic

dermatitis: Insights to pathogenesis, evaluation and management. J Allergy Ther 5 (6):1000195, 2014.

10. Oettgen HC. Fifty years later: emerging functions of $\operatorname{IgE}$ antibodies in host defense, immune regulation, and allergic diseases. $J$ Allergy Clin Immunol 137:1631-45, 2016.

11. Nomura T, Kabashima K, Miyachi Y. The panoply of alpha beta $\mathrm{T}$ cells in the skin. $J$ Dermatol Sci 76:3-9, 2014.

12. Jin S, Park CO, Shin JU, Noh JY, Lee YS, Lee NR et.al. DAMP molecules S100A9 and S100A8 activated by IL-17A and house-dust mites are increased in atopic dermatitis. Exp Dermatol 32:938-41, 2014.

13. Mollanazar NK, Smith PK, Yosipovitch G. Mediators of chronic pruritus in atopic dermatitis: Getting the itch out. Clin Rev Allergy Immunol 1 (3) :263-92, 2015.

14. Mochizuki H, Tanaka S, Morita T , Wasaka T, Sadato N, Kakigi R.The cerebral representation of scratching-induced pleasantness. J Neurophysiol 111: 488-98, 2014.

15. Tsukumo $Y$, Harada $D$, Manabe $H$. Pharmacological Characterization of Itch-
Associated Response Induced by Repeated Application of Oxazolone in Mice. $J$ Pharmacol Scien 113 (3): 255- 62, 2010.

16. Man MQ, Hatano Y, Lee SH, Man M, Chang S, Feingold KR et.al. Characterization of a hapten-induced, murine model with multiple features of atopic dermatitis: structural, immunologic, and biochemical changes following single versus multiple oxazolone challenges. $J$ Invest Dermatol 128(1):79-86, 2008.

17. Meno-Tetang GM L, Lowe PJ. On the prediction of the human response: A recycled mechanistic pharmacokinetic/ pharmacodynamics approach. Basic Clin Pharmacol Toxicol 96: 182-92, 2005.

18. Peng J, Huan Y, Jiang Q, Sun S. J., Jia C. M. , Shen, Z. F. Effects and Potential Mechanisms of Pioglitazone on Lipid Metabolism in Obese Diabetic KKAy Mice. PPAR research, 538183, 2014.

19. Costa R, Manjavachi MN, Motta EM, Marotta DM, Juliano L, Torres HA et. al . The role of kinin B1 and B2 receptors in the scratching behaviour induced by proteinaseactivated receptor-2 agonists in mice. $\mathrm{Br} J$ Pharmacol 159(4): 888-97, 2010.

20.Mehanna RA, Nabil I, Attia N, Bary AA, Razek KA, Ahmed TA et.al . The Effect of Bone Marrow-Derived Mesenchymal Stem Cells and Their Conditioned Media Topically Delivered in Fibrin Glue on Chronic Wound Healing in Rats. Biomed Res Int. 2015:846062, 2015.

21.Matsuoka H, Maki N, Yoshida S, Arai M, Wang J, Oikawa Y et. al. A mouse model of atopic eczema/dermatitis syndrome by 
repeated application of a crude extract of house-dust mite Dermatophagoides farina. Allergy 58:139-45, 2003.

22. Heo WI, Lee KE, Hong JY, Kim MN, Oh MS, Kim YS et. al. The role of interleukin17 in mouse models of atopic dermatitis and contact dermatitis. Clin Exp Dermatol 40(6):665-71, 2015.

23.Czarnowicki T, Gonzalez J, Bonifacio KM, Shemer A, Xiangyu P, Kunjravia N et.al. Diverse activation and differentiation of multiple B cell subsets in patients with atopic dermatitis but not in patients with psoriasis. $J$ allergy Clin Immunol 137:118-29.e5, 2016.

24. Martin SF, Esser PR, Weber FC, Jakob T, Freudenberg MA, Schmidt M et.al . Mechanisms of chemical-induced innate immunity in allergic contact dermatitis. Allergy 66(9):1152-63, 2011.

25. Liu B, Tai Y, Liu B, Caceres AI, Yin C, Jordt SE. Transcriptome profiling reveals Th2 bias and identifies endogenous itch mediators in poison ivy contact dermatitis. JCI Insight. 11;5(14):e124497, 2019.

26.Nakajima S, Kitoh A, Egawa G, Natsuaki Y, Nakamizo S, Moniaga CS et. al .IL-17A as an inducer for Th2 immune responses in murine atopic dermatitis models. J Invest Dermatol 134(8):2122-30, 2014.

27.Gutowska-Owsiak D, Schaupp AL, Salimi M, Selvakumar TA, McPherson T, Taylor S et. al . IL-17 downregulates filaggrin and affects keratinocyte expression of genes associated with cellular adhesion. Exp Dermatol 21(2):104-10, 2012.

28. Floudas A, Saunders SP, Moran T, Schwartz C, Hams E, Fitzgerald DC et. al.
IL-17 Receptor A Maintains and Protects the Skin Barrier To Prevent Allergic Skin Inflammation. $J$ Immunol 199(2):707-17, 2017.

29. Milovanovic M, Drozdenko G, Weise C, Babina M, Worm M. Interleukin-17A promotes IgE production in human B cells. $J$ Invest Dermatol 130(11):2621-8, 2010.

30. Doreau A, Belot A, Bastid J, Riche B, Trescol-Biemont MC, Ranchin B et. al . Interleukin 17 acts in synergy with B cellactivating factor to influence B cell biology and the pathophysiology of systemic lupus erythematosus. Nat Immunol 10(7):778-85, 2019.

31. Tabatabian F, Ledford DK. Omalizumab for severe asthma: toward personalized treatment based on biomarker profile and clinical history, J Asthma Allergy 11: 53-61, 2018.

32.Desouza CV, Shivaswamy V. Pioglitazone in the treatment of type 2 diabetes: safety and efficacy review. Clin Med Insights Endocrinol Diabetes 3:43-5, 2010.

33. Wendy B. Bollag WB, Aitkens L, White J, Hyndman $\mathbf{K}$ A. Aquaporin-3 in the epidermis: more than skin deep. Am J Physiol Cell Physiol 318: C1144-C1153, 2020

34. Iglesias J, Morales L, Barreto GE. Metabolic and inflammatory adaptation of reactive astrocytes: Role of PPARs. Mol Neurobiol 54; (4): 2518-38, 2017.

35. Dahten A, Koch C, Ernst D, Schnöller C, Hartmann S, Worm M. Systemic PPAR ligation inhibits allergic immune response in the skin. J Invest Dermatol 128: 2211-8, 2008. 
36. Gim H.J, Choi Y S, Li H, Kim Y J, Ryu J

$\mathbf{H}$,Jeon R. Identification of novel PPAR $\gamma$ agonist through scaffold tuning approach. Int J Mol Sci 19: 3032, 2018.

37.Narala VR, Ranga R, Smith MR, Berlin AA, Standiford TJ, Lukacs NW et.al.

Pioglitazone is as effective as dexamethasone in a cockroach allergen-induced murine model of asthma. Respir Res 8(1) :90, 2007. 